\title{
Differential diagnoses of hyperandrogenism in a post menopausal woman
}

\author{
K Dharshini $^{1}$, Uditha Bulugahapitiya ${ }^{2}$ \\ Sri Lanka Journal of Diabetes, Endocrinology and Metabolism 2013; 3: 95-97
}

\begin{abstract}
Evaluation of postmenopausal women with hyperandrogenism should be focused to identify the underlying pathology. Clinicians should have high degree of suspicion. The spectrum of differential diagnoses could be more sinister causes like androgen secreting adrenal and ovarian tumours in one end and the polycystic ovarian syndrome in the other end. We describe a postmenopausal woman who presented with hyperandrogenism due to Sertoli-Leydig cell tumour of the ovary. Her testosterone levels returned to normal four weeks after surgery.
\end{abstract}

Key words: post menopause, hyperandogenism, Sertoli-Leydig cell, ovarian tumour.

\section{Introduction}

The clinical presentation of hyperandrogenism in postmenopausal women may be atypical and late, because disturbance in the menstrual cycle and pattern of hair growth could be attributed to normal aging. Evaluation should be focused to identify the possible underlying pathology. Although rare, ovarian and adrenal tumours should be considered in the differential diagnoses, as early detection has good prognosis.

\section{Case report}

A 58 year old postmenopausal woman was referred to us with a history of increased facial and body hair for one year duration and deepening of voice for 3 years. Her menstrual periods had been regular until she reached menopause at the age of 47 years. Her medical history was notable for hypertension diagnosed 4 years ago and osteosarcoma of left tibia and surgical above knee amputation 18 years ago. She was a mother of two children and denied having a family history of hirsutism or androgenic disorders.

On physical examination, she had male pattern frontotemporal balding and hirsutism (Figure 1). Regular hair removal made difficulties in scoring the severity of hirsutism. Pelvic examination showed no palpable masses or clitoromegaly.
She had elevated levels of serum total testosterone with $3.82 \mathrm{ng} / \mathrm{ml}$ (normal range 0.15 to 0.81 ). Her folliclestimulating hormone (FSH) and luteinizing hormone ( $\mathrm{LH})$ values were 28.4 and $32 \mathrm{IU} / \mathrm{L}$ respectively compatible with postmenopausal state. She had normal levels of dehydroepiandrosterone sulfate (DHEAS) which was $17.5 \mu \mathrm{g} / \mathrm{ml}$ (3.5 - 43). Her $17 \beta$-hydroxyprogesterone was also within normal range, $0.46 \mathrm{ng} / \mathrm{ml}$. She had normal cortisol response to overnight dexamethazone suppression test. Her testosterone level was not suppressed with low dose dexamethazone suppression test. This indicates possible ovarian source for her hyperandrogenism, since more than $40 \%$ suppression would be expected if it is from adrenal source. Transvaginal ultrasonography revealed an enlarged right ovary. A computed tomographic scan of the abdomen and pelvis showed normal adrenal glands and an ill defined mass in right adenexial area.

Since both biochemical and imaging studies localized the source of the hyperandrogenism to ovarires, the patient was offered hysterectomy and bilateral salphingo oophorectomy. Intra-operatively the right ovary was enlarged without any adhesions to surrounding structures (Figure 2). Histology confirmed intermediate differentiated sertoli-Leydig cell tumour of right ovary. Four weeks post operatively her serum testosterone returned to normal levels.

${ }^{1}$ Senior Registrar in Endocrinology, National Hospital of Sri Lanka, ${ }^{2}$ Consultant Endocrinologist, Teaching Hospital, Kalubowila, Sri Lanka. 


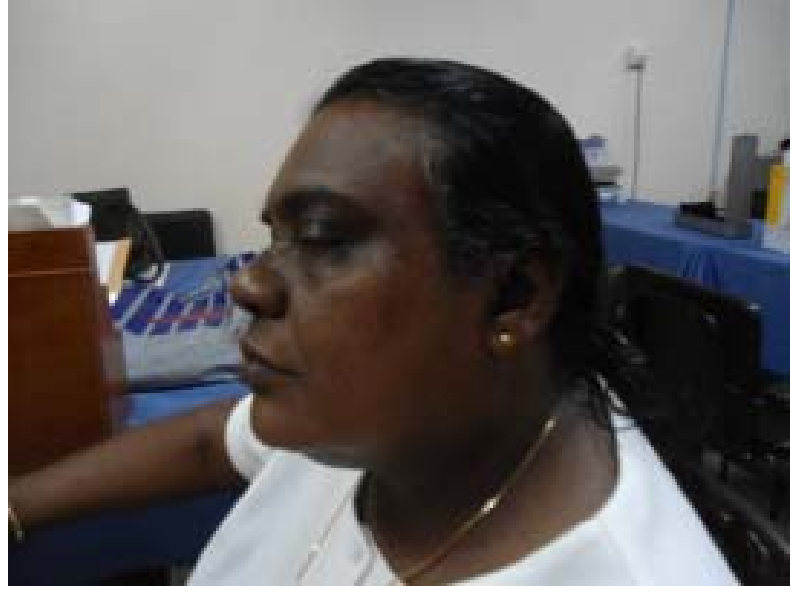

Figure 1. Male pattern frontotemporal balding.

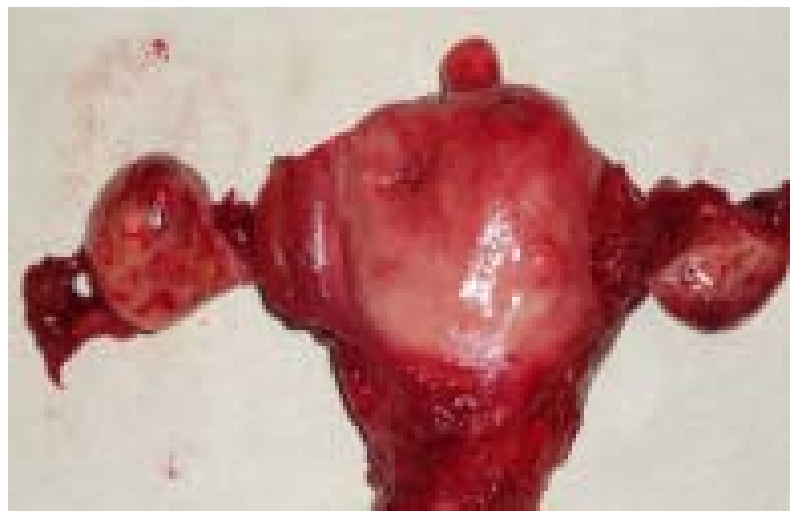

Figure 2. Enlarged right ovary.

\section{Discussion}

This case describes a post menopausal female who presented with hyperandrogenism due to sertoli-leydig cell tumour of ovary. This tumour is a rare ovarian tumour often detected in young women and very rare in post menopausal age. Therefore clinicians should consider all potential underlying causes of hyperandrogenism when postmenopausal women presented with hirsuitism.

Currently the literature is sparce concerning the long term effects of hyperandrogenism in menopausal women. Nevertheless the recent reports indicate association between high androgens and several metabolic derangements. These includes altered lipids (1), insulin resistance, obesity, diabetes (2), advanced glycation end products (3), fluid retention, elevation in haematocrit and hypertension (4), as well as high risk for breast cancer (5) and cardiovascular disease (2). To prevent these long term negative health consequences androgen excess should be detected and treated appropriately.

The possible differential diagnoses are summarized in Table 1. Poly cystic ovarian syndrome (PCOS) is a most common cause for hyperandrogenism in premenopausal women. As there is no sharp decline in ovarian testosterone production during menopause, late diagnosis of PCOS is not a rare entity $(6,7)$. Hyperthecosis, a severe form of PCOS due to overproduction of androgens by ovarian stromal cells as a result of high levels of gonadotrophines in postmenopausal women also need to be considered (8). Obesity induced hyperandrogenism, an entity where signs of hyperandrogenism develop with weight gain. Women will have cystic ovaries without elevated LH/FSH ratio. The excessive local production of oestrogens and androgens by surplus aromatase and 5 alpha reductase activity in adipose tissue is the possible mechanism (7).

Table 1. Differential diagnoses of postmenopausal hyperandrogenism

\begin{tabular}{|c|c|}
\hline Diagnoses & Clinical clues \\
\hline $\begin{array}{l}\text { Polycytic ovarian } \\
\text { syndrome }\end{array}$ & $\begin{array}{l}\text { Long duration and } \\
\text { features of hyperandro- } \\
\text { genism prior to menopause. }\end{array}$ \\
\hline Ovarian hyperthecosis & $\begin{array}{l}\text { Long history, more severe } \\
\text { hirsuitism and virilization. }\end{array}$ \\
\hline $\begin{array}{l}\text { Obesity induced } \\
\text { hyperandrogenism }\end{array}$ & $\begin{array}{l}\text { Timing of hyperandro- } \\
\text { genism correlate with } \\
\text { weight gain and symptoms } \\
\text { reverse with weight loss. }\end{array}$ \\
\hline $\begin{array}{l}\text { Androgen secreting } \\
\text { ovarian or adrenal tumours }\end{array}$ & $\begin{array}{l}\text { Rapidly onset, more severe } \\
\text { hyperandrogenism. }\end{array}$ \\
\hline Cushing syndrome & Cushingoid features \\
\hline Iatrogenic & $\begin{array}{l}\text { Medications such as } \\
\text { DHEA supplements and } \\
\text { exposure to male partners' } \\
\text { testosterone gel. }\end{array}$ \\
\hline
\end{tabular}

Ovarian or adrenal tumours produce high levels of androgens and patients usually present with virilization of short duration (9). Adrenal tumours secreting DHEA, DHEAS and rarely testosterone, will cause hyperandrogenic picture and patients with adrenal carcinoma will have high levels of DHEAS (10).

Androgen producing ovarian tumours include sertoli cell and leydig cell tumours, steroid cell tumours not otherwise specified and ovarian thecoma (11). SertoliLeydig cell tumours constitute less than $0.5 \%$ of ovarian tumours. Depending on the differentiation, it behaves as benign or malignant fashion (12). Steroid cell tumours account for $0.1 \%$ of ovarian tumours. These are usually 
benign with relatively long history of androgenic changes (13). Ovarian thecoma is typically present in older women with majority in postmenopausal period. These account for 0.5 to $1 \%$ and they mainly secrete oestrogen. But they are virilizing in $10 \%(14)$.

Therapeutic options for post menopausal women with hyperandrogenism depend on the aetiology. Surgical cure for adrenal and ovarian tumors, with total hysterectomy and bilateral oophorectomy is a suitable surgical option in post menopausal females with ovarian tumours as in our patient (13). Whereas in young women unilateral oophorectomy is desired and patients can avoid exogenous hormone replacement $(15,16)$. Although there is no standard regime, for patients with malignant sertolileydig cell tumours platinum based adjuvant chemotherapy is recommended following surgery (17).

\section{Conclusion}

This case illustrates the rare possibility of SertoliLeydig cell tumour of ovary in a postmenopausal woman with hyperandrogenism. She had a relatively long history of symptoms, though androgen producing ovarian tumours typically have rapid onset of symptoms. This explains the importance of high degree of clinical suspicion when evaluating older women with hirsuitism.

\section{References}

1. Wild RA, Carmina E, Diamanti-Kandarakis E, et al. Assessment of cardiovascular risk and prevention of cardiovascular disease in women with the polycystic ovary syndrome: a consensus statement by the Androgen Excess and Polycystic ovary Syndrome (AE-PCOS) Society. Journal of Clinical Endocrinology and Metabolism 2010; 95: 2038-49.

2. Shaw LJ, Bairey Merz CN, Azziz, R, et al. Postmenopausal women with a history of irregular menses and elevated androgen measurements at high risk for worsening cardiovascular event-free survival: results from the National Institutes of Health - National Heart, Lung, and Blood Institute sponsored Women's Ischemia Syndrome Evaluation. Journal of Clinical Endocrinology and Metabolism 2008; 93: 1276-84.

3. Diamanti-Kandarakis E, Lambrinoudaki I, Economou F, et al. Androgens associated with advanced glycation end- products in postmenopausal women. Menopause 2010; 17: 1182-7.

4. Yetkin DO, Demirsoy ET, Kadioglu P. Pure leydig cell tumour of the ovary in a post-menopausal patient with severe hyperandrogenism and erythrocytosis. Gynecological Endocrinology 2011; 27: 237-40.

5. Dorgan JF, Stanczyk FZ, Kahle LL, et al. Prospective casecontrol study of premenopausal serum estradiol and testosterone levels and breast cancer risk. Breast Cancer Research 1 2011; 2: 98.

6. Davison SL, Bell R, Donath S, et al. Androgen levels in adult females: changes with age, menopause, and oophorectomy. Journal of Clinical Endocrinology and Metabolism 2005; 90: 3847-53.

7. Micol S, Rothman, Margaret E, Wierman. How should postmenopausal androgen excess be evaluated? Clinical Endocrinology 2011; 75: 160-4.

8. Krug E, Berga SL. Postmenopausal hyperthecosis: functional dysregulation of androgenesis in climacteric ovary. Obstetrics and Gynecology 2002; 99: 893-7.

9. Morgan LS. Hormonally active gynecologic tumors. Seminars in Surgical Oncology 1990; 6: 83-90.

10. Cordera F, Grant C, van Heerden J, et al. Androgensecreting adrenal tumors. Surgery 2003; 134: 874-80.

11. Young RH, Scully RE. Ovarian Sertoli-Leydig cell tumors. A clinicopathological analysis of 207 cases. The American Journal of Surg Pathology 1985; 9: 543-69.

12. Markham M. Gynecologic cancers. In Goldman L, Schafer AI, eds. Cecil Medicine. 24th ed. Philadelphia, PA: Saunders Elsevier; 2011: chap 205.

13. Powell JL, Dulaney DP, Shiro BC. Androgen-Secreting Steroid Cell Tumor of the Ovary. South Med J 2000; 93:

14. Keeney GL. Ovarian tumors with endocrine manifestations. In: De Groot LJ, editor. Endocrinology. 4th ed. Philadelphia (PA): WB Saunders Company; 2001: 2172.

15. Gershenson DM. Management of early ovarian cancer: germ cell and sex cord-stromal tumors. Gynecol Oncol 1994; 55 : S62.

16. Zhang M, Cheung MK, Shin JY, et al. Prognostic factors responsible for survival in sex cord stromal tumors of the ovary an analysis of 376 women. Gynecol Oncol 2007; 104: 396.

17. National Comprehensive Cancer Network ( $\mathrm{NCCN})$ guidelines. 